\title{
Membangun Kinerja Organisasi Melalui Komunikasi Interpersonal pada Organisasi Bisnis Pendidikan di Kota Pekanbaru
}

\author{
Masirun \\ Dosen Fakultas Ekonomi Universitas Lancang Kuning \\ Email: masirun@unilak.ac.id
}

\begin{abstract}
Business organizations are effective in achieving its objectives requires the power of communication both owned personally and of the organization itself. This study proves that using the case of the commercial business organizations in the city of Pekanbaru with the use of a sample of educators as many as 56 people in the census and data collection using questionnaires and analyzed with simple regression showed that the interpersonal communication significantly influence the performance of the business organization.
\end{abstract}

Keywords: organizational performance, interpersonal communication

Perubahan dunia pendidikan yang makin pesat, telah mengakui eksistensi seorang guru secara individual yang harus mendapatkan perhatian dari banyak kalangan. Perhatian ini seperti dari pemerintah, yakni sebagai pihak yang membutuhkan tenaga pengajar kemudian masyarakat sebagai pihak yang memerlukan seorang berilmu untuk memberikan ilmunya kepada anak-anak mereka.

Tenaga pendidikans merupakan sumberdaya yang sangat berperan dalam memberikan pelayanan pendidikan kepada peserta didik, guru ini merupakan ujung tombak pelayanan kepada peserta didik, dimana pengajaran langsung diberikan oleh guru kepada peserta didik. Oleh karenanya kepuasan guru dalam memberikan pelajaran kepada peserta didik dirasakan penting dan perlu mendapatkan perhatian dari berbagai kalangan karena akan memberikan dampak pada pelayanan yang diberikannya kepada peserta didik.

Prestasi dalam pendidikan menjadi kata kunci sebuah oragnisasi bisnis. Lawler dan Porter dalam Sutrisno (2010: 170) menyatakan prestasi sama dengan kinerja, dimana kinerja adalah kesuksesan seseorang dalam melaksanakan tugas. Kemudian menurut Miner dalam Sutrisno (2010: 170) menyatakan kinerja adalah bagaimana seseorang diharapkan dapat berfungsi dan berperilaku sesuai dengan tugas yang telah dibebankan kepadanya.
Widodo (2001: 47) menjelaskan bahwa kinerja adalah sesuatu yang dicapai, prestasi yang diperlihatkan dan kemampuan kerja. Kemudian menurut Mangkunegara, (2000: 67) istilah kinerja dari kata job performance atau actual performance (prestasi kerja atau prestasi, sesungguhnya yang dicapai seseorang). Pengertian kinerja adalah hasil kerja secara kualitas dan kuantitas yang dicapai oleh seseorang dalam melaksanakan tugasnya sesuai dengan tanggung jawab yang diberikan kepadanya. Selanjutnya dapat dipahami kinerja aparat mempengaruhi kinerja organisasi dimana dia berperan sebagai pelaku.

Menurut Soeprihanto (2000: 8), secara lebih rinci menyebutkan bahwa tujuan penilaian pelaksanaan pekerjaan (kinerja) sebagai berikut: 1) Mengetahui keadaan keterampilan dan kemampuan setiap pegawai secara rutin. 2) Untuk digunakan sebagai dasar perencanaan bidang personalia, khususnya penyempurnaan kondisi kerja, peningkatan mutu dan hasil kerja. 3) Dapat digunakan sebagai dasar pengembangan dan pendayagunaan pegawai seoptimal mungkin, sehingga antara lain dapat diarahkan jenjang karirnya atau perencanaan karir, kenaikan pangkat dan kenaikan jabatan. 4) Mendorong terjadinya hubungan timbal balik antara atasan dan bawahan. 5) Mengetahui kondisi organisasi 
secara keseluruhan dari bidang personalia, khususnya kinerja pegawai. 6) Secara pribadi pegawai dapat mengetahui kekuatan dan kelemahan masing-masing sehingga dapat memacu perkembangan. 7) Hasil evaluasi kinerja dapat bermanfaat bagi penelitian dan pengembangan di bidang personalia secara keseluruhan.

Berbicara masalah prestasi lembaga pendidikan saat ini menjadi hal yang menarik untuk dibahas, karena selain sebagai sekolah pariwisata sebagai penyedia tenaga teknis kepariwisataan juga sebagai pencetak tenaga kerja yang siap kerja. Permasalahan atau fenomena yang muncul di lapangan berkaitan dengan prestasi yang dihasilkan oleh sekolah seperti prestasi dalam perlombaan, memasuki dunia kerja dan juga dalam mencapai nilai rata-rata kelulusan dan bahkan dalam mengisi kesempatan kerja.

Persoalan komunikasi interpersonal antar guru dalam melaksanakan tugas yang berhubungan dengan guru lainnya kurang harmonis, dimana dapat diketahui bahwa sebagian guru berusaha untuk menyenangkan kepala sekolah dalam mencapai targetnya dan kondisi ini dilakukan dengan tidak memperdulikan sesama guru dan bahkan selalu terdengar kata-kata kasar antar guru dalam berkomunikasi. Kejadian seperti ini sepertinya suatu kejadian yang disengajar dan sudah berlangsung semenjak lama sehingga sebagian dari guru ada yang merasa kurang nyaman dengan kondisi tersebut.

Menurut Effendy (2003: 30) adalah penyampaian pesan oleh satu orang dan penerimaan pesan oleh orang lain atau sekelompok kecil orang, dengan berbagai dampaknya dan dengan peluang untuk memberikan umpan balik segera. Dimensinya menuru Siagian (2004: 131) menyatakan ada beberapa dimensi komunikasi interpersonal adalah: 1). Percaya (trust) sebagai bentuk saling percaya dalam sekelompok guru yang bersama memberikan pembelajaran; 2). Perilaku suportif sebagai usaha saling mendukung berbagai aktifitas kegiatan; 3). Sikap terbuka sebagai bentuk tidak ada rahasia dalam berkomunikasi.
Komunikasi interpersonal menurut Effendy (2003: 30) adalah penyampaian pesan oleh satu orang dan penerimaan pesan oleh orang lain atau sekelompok kecil orang, dengan berbagai dampaknya dan dengan peluang untuk memberikan umpan balik segera. Menurut Sunarto (2003: 13) bahwa komunikasi antar komunikator dengan komunikan, komunikasi jenis ini dianggap paling efektif dalam upaya mengubah sikap, pendapat atau perilaku seseorang, karena sifatnya yang dialogis berupa percakapan. Arus balik bersifat langsung, komunikator mengetahui tanggapan komunikan ketika itu juga. Pada saat komunikasi dilancarkan, komunikator mengetahui secara pasti apakah komunikasinya positif atau negatif, berhasil atau tidaknya. Jika ia dapat memberikan kesempatan pada komunikan untuk bertanya seluas-luasnya

Kata komunikasi menurut Wursanto (2003: 153) mempunyai banyak arti. Menurut asal katanya (etimologi) istilah komunikasi berasal dari bahasa latin, yaitu communis yang berarti sama (common), dari kata communis berubah menjadi kata kerja kommunicare yang berarti penyebaran atau memberitahukan. Jadi dari asal usul katanya berarti komunikasi adalah penyebaran atau memberitahukan. Beberapa pendapat ahli mendefinisikan konsep komunikasi interpersonal. Menurut Ronal (1996: 129), komunikasi merupakan faktor penting dalam menciptakan kerjasama dalam organisasi. Komunikasi yang tidak efektif bisa mengakibatkan ketegangan hubungan di kalangan anggota organisasi, sehingga menghambat kerjasama antar organisasi dan pada gilirannya menyulitkan pertumbuhan organisasi secara sehat. Kemudian juga hal senada disampaikan oleh Stoner (1996: 125) komunikasi didefinisikan sebagai proses yang dipergunakan oleh manusia untuk mencari kesamaan arti lewat transmisi pesan simbolik. Dari pendapat tersebut dijelaskan bahwa komunikasi interpersonal merupakan proses yang 
dipergunakan manusia sebagai individu dalam mencari sebuah kesamaan.

Dari pendapat tersebut dapat dinyatakan bahwa komunikasi interpersonal sebagai suatu proses dengan mana orangorang bermaksud memberikan pengertianpengertian melalui pengiringan berita secara simbolis, dapat menghubungkan para anggota berbagai satuan yang berbeda dan bidang yang berbeda pula, sehingga sering disebut rantai pertukaran informasi. Konsep ini mempunyai unsur-unsur: 1) suatu kegiatan untuk membuat seseorang mengerti, 2) suatu sarana pengaliran informasi dan , 3) suatu sistem bagi terjalinnya komunikasi diantara individu-individu. Pandangan tradisional tentang komunikasi telah banyak diubah oleh perkembangan teknologi, yaitu bahwa komunikasi tidak hanya terjadi antara dua atau lebih individu, tetapi juga mencakup juga komunikasi antara orang-orang dan mesin-mesin, dan bahkan antara mesin dengan mesin lainnya.

Menurut Newstrom (2007: 56) "employe at lower levels have a number of communication need. Managers think that they understand employees' needs, but often their employees do not think so". (artinya pegawai di tingkat bawah memiliki sejumlah kebutuhan komunikasi. Manajer berpikir bahwa mereka memahami kebutuhan karyawan, tetapi sering karyawan mereka tidak berpikir begitu). Kemudian dijelaskan juga bahwa "one communication need of employees is proper instruction regarding their work" (artinya salah satu kebutuhan komunikasi karyawan adalah instruksi yang tepat mengenai pekerjaan mereka).

Selain itu juga menurut Kreitner (2007: 440) bahwa; "the quality of interpersonal communication within an organization is very important. People with good communication skills helped groups to make more innovative decisions and were promoted more frequently than individuals with less developed abilities". (artinya kualitas komunikasi interpersonal dalam suatu organisasi sangat penting. Orang dengan kemampuan komunikasi yang baik membantu kelompok untuk membuat keputusan yang lebih inovatif dan dipromosikan lebih sering daripada individu dengan kemampuan yang kurang berkembang).

Menurut Siagian (2004: 131) menyatakan ada beberapa faktor komunikasi interpersonal adalah: 1). Percaya (trust). Bila seseorang punya perasaan bahwa dirinya tidak akan dirugikan, tidak akan dikhianati, maka orang itu pasti akan lebih mudah membuka dirinya; 2) Perilaku suportif akan meningkatkan kualitas komunikasi; 3). Sikap terbuka, kemampuan menilai secara obyektif, kemampuan membedakan dengan mudah, kemampuan melihat nuansa, orientasi ke isi, pencarian informasi dari berbagai sumber, kesediaan mengubah keyakinannya, profesional dll.

Berdasarkan uraian di atas maka dapat didefinisikan bahwa komunikasi interpersonal yaitu suatu proses komunikasi yang bersetting pada objek-objek sosial untuk mengetahui pemaknaan suatu stimulus.

Penelitian ini ingin membuktikan apakah komunikasi interpersonal dalam dunia pendidikan memiliki pengaruh terhadap kinerja organisasi bisnis tersebut.

\section{METODE}

Penelitian ini membuktikan bahwa dengan menggunakan kasus pada organisasi bisnis komersial di Kota Pekanbaru dengan penggunaan sampel dari tenaga pendidik sebanyak 56 orang secara sensus dan pengumpulan data dengan menggunakan kuesioner serta dianalisis dengan regresi sederhana

\section{HASIL}

Kinerja organisasi bisnis pendidikan sekolah adalah kesuksesan suatu lembaga dalam melaksanakan tugas yakni dalam rangka mencerdaskan kehidupan berbangsa. Dimensi kinerja organisasi bisnis pendidikaantara lain produktivitas sebagai hasil keluaran yang diperoleh, kemudian kualitas layanan sebagai bentuk mutu dari yang diberikan kepada keluaran,

$$
\text { p.ISSN: 2407-800X e.ISSN: 2541-4356 }
$$


responsivitas sebagai tanggap terhadap berbagai tuntutan pelanggan dan responsibilitas sebagai sesuai dengan SOPnya serta akuntabilitas sebagai pertanggungjawaban pelaksanaan kegiatan pembelajaran.

Skor atau tingkat capaian rata-rata (TCR) kinerja organisasi bisnis pendidika di Pekanbaru berada pada tingkat baik dengan nilai 3,23 atau TCR 64,5\%. Ini berarti bahwa sekolah selalu mengikuti perlombaan baik skala daerah maupun nasional, sekolah berhasil meluluskan siswa secara $100 \%$, sekolah selalu mendapatkan nomor bagus dalam perlombaan dan lulusan sekolah selalu diterima di pasaran kerja, sekolah menyediakan kotak saran untuk menampung kritik dan saran serta sekolah menindaklanjuti kritik dan saran dari warga sekolah, sekolah menerapkan prosedur yang ketat dan sekolah berjalan secara sistematis, sekolah mendapatkan pujian dari pemerintah, guru merasa puas bekerja sebagai guru di sekolah ini dan masyarakat merasa puas menyekolahkan putra putrinya di sekolah ini.

Komunikasi interpersonal adalah penyampaian pesan oleh satu orang dan penerimaan pesan oleh orang lain atau sekelompok kecil orang, dengan berbagai dampaknya dan dengan peluang untuk memberikan umpan balik segera. Dimensi komunikasi interpsersonal tersebut antara lain percaya (trust) sebagai bentuk saling percaya dalam sekelompok guru yang bersama memberikan pembelajaran, perilaku suportif sebagai usaha saling mendukung berbagai aktifitas kegiatan dan sikap terbuka sebagai bentuk tidak ada rahasia dalam berkomunikasi.

Skor atau tingkat capaian rata-rata (TCR) komunikasi interpersonal pada SMK di Pekanbaru berada pada tingkat cukup dengan nilai 2,95 atau TCR 59\%, ini karena sesama guru masih belum terjalin situasi saling percaya, guru saling menjaga aib sesama guru dan guru saling menutupi kekurangannya, guru belum saling mendukung dalam bekerja, guru saling memberikan nasehat dalam bekerja dengan sesama guru dan guru saling intropeksi diri dalam bekerja, guru belum saling terbuka sesama guru dalam bekerja, guru belum memberikan solusi dari permasalahan yang dihadapi dan guru selalu mencari pemecahan masalah yang terjadi sesama guru.

Pengujian hipotesis lainnya dapat dilakukan dengan membandingkan antara nilai sig dengan nilai apha dengan kreteria: apabila nilai sig lebih besar dari nilai alpha maka pengaruh variabel tidak signifikan. Sebaliknya apabila nilai sig lebih kecil dari nilai alpha maka pengaruh variabel signifikan.

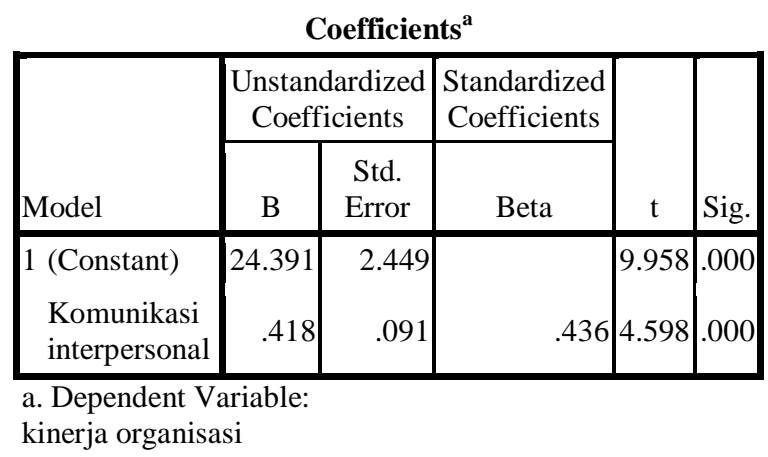

Hasil pengujian coeficient seperti disajikan pada tabel di atas menunjukkan bahwa nilai persamaan regresi berganda yang dihasilkan sebagai berikut:

$\hat{\mathbf{Y}}=\mathbf{2 4 , 3 9 1}+\mathbf{0 , 4 1 8 X}$

Dimana:

$\hat{\mathrm{Y}} \quad=$ Kinerja organisasi

$\mathrm{X}=$ Komunikasi Interpersonal

Pengertian dari persamaan tersebut adalah:

a. Konstanta sebesar 24,391 menyatakan bahwa jika tidak ada variabel komunikasi interpersonal maka nilai kinerja organisasi bisnis pendidikaadalah sebesar 24,391 satuan.

b. Koefisien regresi $\mathrm{X}$ sebesar 0,418 menyatakan bahwa setiap penambahan satu satuan variabel komunikasi interpersonal maka akan meningkatkan kinerja organisasi

p.ISSN: $2407-800 X \quad$ e.ISSN: $2541-4356$ 
bisnis pendidika sebesar 0,418 satuan.

\section{PEMBAHASAN}

Pengaruh komunikasi interpersonal terhadap kinerja organisasi bisnis pendidikadi Kota Pekanbaru ditunjukkan dengan nilai 0,250 , yang berarti jika terjadi kenaikan komunikasi interpersonal sebesar satu satuan maka akan terjadi kenaikan terhadap kinerja organisasi bisnis pendidikasebesar 0,250 satuan, dengan asumsi variabel lainnya konstan. Hasil uji statistik menunjukkan signifikansi pada tingkat keyakinan 95\%. Nilai $t$ hitung variabel komunikasi interpersonal lebih besar dari $\mathrm{t} \alpha / 2$, yaitu 3,046>1,980 dengan tingkat signifikansi $\mathrm{t}$ sebesar 0,003 , maka secara parsial variabel komunikasi interpersonal mempunyai pengaruh positif dan signifikan terhadap prestasi SMK, dengan tingkat keyakninan $95 \%$.

Melalui komunikasi interpersonal sesama guru masih belum terjalin situasi saling percaya, guru saling menjaga aib sesama guru dan guru saling menutupi kekurangannya, guru belum saling mendukung dalam bekerja, guru saling memberikan nasehat dalam bekerja dengan sesama guru dan guru saling intropeksi diri dalam bekerja, guru belum saling terbuka sesama guru dalam bekerja, guru belum memberikan solusi dari permasalahan yang dihadapi dan guru selalu mencari pemecahan masalah yang terjadi sesama guru.

Sehingga sekolah selalu mengikuti perlombaan baik skala daerah maupun nasional, sekolah berhasil meluluskan siswa secara $100 \%$, sekolah selalu mendapatkan nomor bagus dalam perlombaan dan lulusan sekolah selalu diterima di pasaran kerja, sekolah menyediakan kotak saran untuk menampung kritik dan saran serta sekolah menindaklanjuti kritik dan saran dari warga sekolah, sekolah menerapkan prosedur yang ketat dan sekolah berjalan secara sistematis, sekolah mendapatkan pujian dari pemerintah, guru merasa puas bekerja sebagai guru di sekolah ini dan masyarakat merasa puas menyekolahkan putra putrinya di sekolah ini.
Hal ini sejalan dengan hasil penelitian Tiara Caesaringga (2011), bahwa pelatihan komunikasi interpersonal secara signifikan dapat meningkatkan kepuasan kerja karyawan $(\mathrm{F}=86,963, \quad \mathrm{p}<0,01)$. Selanjutnya Rosadi (2008) semakin baik jalannya komunikasi interpersonal kepala sekolah maka semakin tinggi kepuasan kerja guru atau sebaliknya jika semakin buruk jalannya komunikasi interpersonal kepala sekolah maka semakin rendah kepuasan kerja guru.

\section{SIMPULAN}

Komunikasi interpersonal Guru berpengaruh positif dan signifikan terhadap kinerja organisasi bisnis pendidikan di Kota Pekanbaru. Diharapkan kepada guru dan warga sekolah untuk dapat meningkatkan komunikasi interpersonal dalam melaksanakan kegiatan belajar mengajar.

\section{DAFTAR RUJUKAN}

Effendy, Onong Uchjana, 2003, Komunikasi Teori dan Praktek, Bandung: Remaja Rosdakarya

Kreitner dan Kinicki. Perilaku Organisasi, (Jakarta: Salemba Empat, 2001).

Kusumawati, Ratna (2008) Analisis Pengaruh Budaya Organisasi Dan Gaya Kepemimpinan Terhadap Kepuasan Kerja Untuk Meningkatkan Kinerja Karyawan (Studi Kasus Pada RS Roemani Semarang). Masters thesis, Program Pasca Sarjana Universitas Diponegoro.

Panggabean, Mutiara Sibarani, Manajemen Sumber Daya Manusia. (Bogor: Ghalia Indonesia, 2004).

Purwanto, Ngalim, 2010, Administrasi dan Supervisi Pendidikan, PT. Remaja Rosdakarya, Bandung. 
Siagian, Sondang, 1996, Manajemen Sumber Daya Manusia, (Jakarta: Bumi Aksara).

Siagian, Sondang, Manajemen Sumber Daya Manusia, (Jakarta: Bumi Aksara, 1996).

Stoner 1996. Management, (USA: Prentice Hall, Inc).
Tiara Caesaringga, 2011,Pengaruh pelatihan komunikasi interpersonal terhadap peningkatan kepuasan kerja karyawan.

Wibowo, Manajemen Kinerja, (Jakarta: Rajawali Press, 2008).

Wursanto, Dasar-Dasar Ilmu Organisasi, (Yogyakarta: Andi Offset, 2003). 